\title{
Book review: Selling the Invisible. A Field Guide to Modern Marketing
}

\section{Harry Beckwith}

Texere Publishing Ltd., 2001; ISBN 1-58799-066-0; paperback; £9.99

As we are constantly being reminded, with over 50 per cent of UK's industry now being classified as in the service sector and this percentage likely to increase, this book appears at an appropriate and timely moment. 'Selling the Invisible' is written by a marketing practitioner, but it may feel equally at home on the shelf of a budding entrepreneur, marketing student or lecturer. In short, there is something for virtually everybody.

Consisting of 11 chapters, subdivided into several short sections, each containing an anecdote, many of which are memorable, the reader is taken through many of the time worn contents of (service) marketing ambit with a refreshing dynamism which makes compelling reading. There are many thought-provoking comments for lecturers seeking to 'beef up' their lectures and seminars. Quotes litter the text and one selected at random: 'Those old Levi jeans of the old economy were products; these new Levi jeans are a service' may inspire more than just a few to read on.

The main body of the text covers the main areas of (service) marketing in the early chapters from primarily a practical aspect, with little serious academic referencing, but seasoned stalwarts such as Michael Porter and Theodore Levitt, clearly add their distinct messages to the appropriate sections to build credibility. Successful service companies (the author quotes McDonalds, Federal Express and Disney) are held up as 'quality' benchmarks which have raised customer expectations and set a standard for others to follow (redefining the competition). The three corporate examples above typify Beckwith's content which, although set in an American context, translate well into a British, or even a global setting. Some of the text may well be old territory for both marketers and practitioners of specialist subjects within marketing, but this is outweighed by the way the author raises the challenge and hence interest factor for many readers focus groups are not let off the hook lightly, being described as 'telling more about group dynamics than market dynamics'.

Beckwith pays particular attention to positioning, both from a company's perspective positioning the service in the mind of the consumer and from a personal stance, eg delivering a sales presentation where positioning may be combined with focus. In the former case, he emphasises that service companies making similar offerings may fail to realise that customers (prospects) 
themselves are their competitors, as the service customer may have three options: using or not using the service, or in many cases doing it themselves. Those students and practitioners undertaking any planning function may be advised to consider (at least some of) the 18 planning fallacies before proceeding.

The author's service pricing strategies and tactics may conform more to conventional marketing wisdom than do many of his other chapters, with a distinct caveat about steering clear of the middle ground in setting prices, but if browsing, do spend two minutes on 'Pricing: a lesson from Picasso' and the subsequent 'Carpenter corollary'. Useful in not only a marketing/business context, but even adding wit at a dinner party.

Beckwith focuses on service brands, refuting his perception of press reports that (service) brands are dying. He argues that in services, a brand is more important than a warranty, mainly due to the heterogeneity of services that generally renders a warranty difficult to implement. At the end of each anecdote or section to emphasise his point,

Beckwith finalises with a caption in bold italics eg $A$ service is a promise and building a brand builds your promise.
Other areas of marketing including consumer behaviour, communications and selling and customer retention are detailed in a similar vein. Any detailed reference to direct marketing is strangely missing.

This book is probably not for those academics and others seeking a deeper study backed by rich seams of bibliography and referencing, unless they wish to relax and skim the wider service marketing perspective. But for marketing practitioners, business, people, business studies students, lecturers, tutors and others, it provides a good opportunity to build on and deepen their understanding of marketing in a light, breezy, amusing, enjoyable and sometimes memorable manner. It may provide innovative ways to explain concepts which students find difficult to understand or retain. It is the sort of book to take on holiday, to read by the pool or at the airport, or have by the bedside and still find that it has contributed to one's intellectual worth at the end of the holiday. To conclude in the author's own vernacular: the book is not a product, it is a service.

Paul Bartlett
Bristol Business School
University of the West of England

Paul Bartlett University of the West of England 